\title{
Response of yellow catfish (Pelteobagrus fulvidraco) to different dietary concentrations of aflatoxin $B 1$ and evaluation of an aflatoxin binder in offsetting its negative effects
}

\section{Respuesta del bagre amarillo (Pelteobagrus fulvidraco) a diferentes concentraciones dietéticas de aflatoxina $B 1$ y la evaluación de una bentonita para contrarrestar sus efectos negativos}

\author{
Xinxia Wang ${ }^{1 \Delta}$, Yizhen Wang ${ }^{1}$, Yongjin $\mathrm{Li}^{1}$, Ming Huang ${ }^{1}$, Yang Gao ${ }^{1}$, Xianfeng Xue ${ }^{1}$, \\ Haiwen Zhang ${ }^{1}$, Pedro Encarnação ${ }^{2}$, Gonçalo A Santos ${ }^{3}$, Rui A Gonçalves ${ }^{3 * \Delta}$ \\ ${ }^{1}$ BIOMIN Holding GMbH, Erber Campus 1, 3131 Getzersdorf, Austria. \\ 2 BIOMIN Singapore Pte Ltd, 3791 Jalan Bukit Merah \#08-08, E-Centre@Redhill, Singapore 159471. \\ 3 Institute of Feed Science, Zhejiang University, No. 866, Yuhangtang Road, Hang Zhou, Zhejiang Province, \\ China. \\ * Corresponding author: Email: rui.goncalves@biomin.net \\ ${ }^{\Delta}$ Both authors contributed equally to this manuscript
}

\begin{abstract}
Aflatoxin B1 (AFB1), produced by Aspergillus flavus and Aspergillus parasiticus, is one of the major mycotoxins to affect animal health. AFB1 contamination of aquafeed is widespread, especially in countries with humid, tropical climates. The most applied method for protecting animals against aflatoxicosis is the use of clay minerals. Growth performance, immunosuppressive effects (bactericidal activity, lysozyme activity, albumin/globulin ratio, alternative complement pathway activity, and protein content), and pathology parameters were used to evaluate the response of yellow catfish (Pelteobagrus fulvidraco) to increasing concentrations of AFB1 and test the protective effect of dietary supplementation with a bentonite (dioctahedral montmorillonite) based AFB1 binder. Triplicate groups of yellow catfish with an average weight of $2.0 \pm 0.1 \mathrm{~g}$ were fed diets containing $0,200,500$, and 1,000 $\mu \mathrm{g} / \mathrm{kg}$ of AFB1 alone, or diets containing $0,200,500$, and $1,000 \mu \mathrm{g} / \mathrm{kg}$ of AFB1 along with $2 \mathrm{~g} / \mathrm{kg}$ AFB1 binder, for 12 weeks. Results showed that diets containing increasing amounts of AFB1 had a significantly lower $(P=0.002)$ survival rate. There was a statistical significant reduction in weight gain, final body weight, and specific growth rate, and an increase in feed conversion ratio (FCR) influenced by the levels of AFB1 in the diet $(P<0.001$ for all parameters), as well as increasing protection due to the presence of the $\operatorname{binder}(P=0.046, P=0.014, P=0.038$, and $P=0.485$, respectively). The immunosuppressive nature of AFB1 in yellow catfish diets was confirmed through observation of lower bactericidal activity $(P=0.001)$, lower lysozyme activity $(P=0.006)$, reduced total protein $(P=0.002)$, and enhanced albumin/globulin ratio $(P=0.004)$. Fish fed diets contaminated with AFB1 and supplemented with the AFB1 binder showed better improvement in FCR $(P=0.019)$. These results indicate that AFB1 has a negative impact on yellow catfish growth and survival rate. The AFB1 binder protected fish from the toxic effects of AFB1.
\end{abstract}

Key words: mycotoxins, aflatoxin B1 (AFB1), growth performance, immunosuppression.

RESUMEN. La aflatoxina B1 (AFB1), producida por Aspergillus flavus y Aspergillus parasiticus, es una de las principales micotoxinas que afectan la salud animal. La contaminación de alimentos acuícolas con AFB1 es común, especialmente en países con climas húmedos y tropicales. El método más usado para proteger a los animales contra la aflatoxicosis es el uso de arcillas. Para evaluar la respuesta del bagre amarillo (Pelteobagrus fulvidraco) a concentraciones crecientes de AFB1 y evaluar el efecto protector de una bentonita (montmorillonita dioctaédrica), se analizaron el crecimiento, efectos inmunosupresores (actividad bactericida, relación albúmina/globulina, actividad de la lisozima, actividad de la vía alternativa del complemento y contenido de proteínas) y parámetros patológicos. Grupos triplicados de $P$. fulvidraco, con un peso promedio de $2.0 \pm 0.1 \mathrm{~g}$, fueron alimentados durante 12 semanas con dietas que contenían $0,200,500 \mathrm{y} 1,000 \mu \mathrm{g} / \mathrm{kg}$ de AFB1 pura, o dietas que contienían 0, 200, 500 y 1,000 $\mu \mathrm{g} / \mathrm{kg}$ de AFB1 junto con $2 \mathrm{~g} / \mathrm{kg}$ de bentonita. Los resultados mostraron que las dietas con mayores cantidades de AFB1 tenían una tasa de supervivencia significativamente menor $(P=0.002)$. Hubo una reducción estadísticamente significativa del aumento de peso, el peso corporal final y la tasa de crecimiento específico y un aumento de la tasa de conversión alimenticia debido a los niveles de AFB1 en la dieta $(P<0.001$ para todos los parámetros), así como mayor protección por la presencia de la bentonita $(P=0.046, P=0.014, P=0.038$ y $P=0.485$, respectivamente). La naturaleza inmunosupresora de AFB1 en las dietas del bagre amarillo se confirmó mediante la observación de una menor actividad bactericida $(P=0.001)$, una menor actividad de la lisozima $(P=0.006)$, una disminución de la proteína total $(P=0.002)$ y una mayor relación albúmina/globulina $(P=0.004)$. Los peces alimentados con dietas contaminadas con AFB1 y complementadas con la bentonita mostraron una mejora de la tasa de conversión alimenticia $(P=0.019)$. Estos resultados indican que la AFB1 tiene un impacto negativo en el crecimiento del bagre amarillo y la tasa de supervivencia. La bentonita protegió a los individuos de los efectos tóxicos de la AFB1.

Palabras clave: micotoxinas, aflatoxina B1 (AFB1), crecimiento, inmunosupresión. 


\section{INTRODUCTION}

Mycotoxin contamination is a problem affecting nearly $25 \%$ of the world's crop production, representing the most important category of biological toxins impacting human and animal health (CAST 2003). According to the annual BIOMIN Mycotoxin Survey (BIOMIN 2014), an even higher percentage of crops are affected by mycotoxins (a prevalence of $66 \%$ and average contamination level of 1,394 parts per billion in 2014).

These toxic secondary metabolites are produced by filamentous fungi that frequently contaminate agricultural commodities used for human and animal feed (Hussein and Brasel 2001, Sudakin 2003). Chemically, mycotoxins display a wide range of structures, differing also in biological effects: carcinogenic, teratogenic, mutagenic, estrogenic, neurotoxic, or immunotoxic (Abd-Allah et al. 1999, McKean et al. 2006, El-Sayed et al. 2009, Hooft et al. 2011). Aflatoxins are polycyclic aromatic hydrocarbons, produced mainly by Aspergillus flavus and Aspergillus parasiticus, but also to a lesser extent by Aspergillus nominus. The main aflatoxins commonly found in feedstuffs are aflatoxin B1 (AFB1), aflatoxin B2 (AFB2), aflatoxin G1 (AFG1), and aflatoxin G2 (AFG2) (Ottinger and Kaattari 1998, 2000; Huang et al. 2011). These mycotoxins occur especially in subtropical and tropical areas, contaminating mainly feedstuffs with high starch and lipid content, such as cottonseed, corn, peanut, wheat, and soybean (Ostrowski-Meissner et al. 1995).

AFB1 is known as the most potent carcinogen among aflatoxins, classified as a group I carcinogen by the International Agency for Research on Cancer (IARC 1993) and highly hepatocarcinogenic (Busby and Wogan 1984, Sharma and Salunkhe 1991, Miller and Trenholm 1994, Wang et al. 1998).

The toxicity and carcinogenicity of AFB1 is thought to be directly linked to its bioactivation. After ingestion, AFB1 is converted in the liver, which results in a highly reactive AFB1-8,9-epoxide (AFBO). This bioactivation occurs primarily by a microsomal cytochrome P450 (CYP450) dependent epoxidation of the terminal furan ring of AFB1 and is responsible for binding to cellular macromolecules such as DNA, RNA, and other protein constituents (Massey et al. 1995, Smith et al. 1997, Wang and Groopman 1999). This will directly result in damage/necrosis of hepatocytes and other metabolically active cells, leading to reduction of body weight, behavioral abnormalities, yellowing of the body surface, and immune suppression (Jantrarotai and Lovell 1990, Chávez-Sánchez et al. 1994, Eaton and Groopman 1994, Sahoo and Mukherjee 2001, Manning et al. 2005, Deng et al. 2010).

In aquaculture production, considerable research has been carried out on the toxicity of AFB1 on fish and crustacean species, including rainbow trout, Oncorhynchus mykiss (Ngethe et al. 1993; Bailey et al. 1994; Ottinger and Kaattari 1998, 2000; Carlson et al. 2001; Hooft et al. 2011; Hanson

\section{INTRODUCCIÓN}

La contaminación por micotoxinas es un problema que afecta casi el $25 \%$ de la producción mundial de cultivos y, por tanto, se consideran la categoría más importante de toxinas biológicas que afectan la salud humana y animal (CAST 2003). Según el estudio anual de BIOMIN (2014), el porcentaje de cultivos afectados por micotoxinas es aún mayor (una prevalencia de $66 \%$ y un nivel promedio de contaminación de 1,394 partes por billón en 2014).

Estos metabolitos secundarios tóxicos son producidos por hongos que con frecuencia contaminan los productos agrícolas que se usan para la alimentación humana y animal (Hussein y Brasel 2001, Sudakin 2003). Las micotoxinas presentan una amplia gama de estructuras químicas y sus efectos biológicos pueden ser carcinogénicos, teratogénicos, mutagénicos, estrogénicos, neurotóxicos o inmunotóxicos (Abd-Allah et al. 1999, McKean et al. 2006, El-Sayed et al. 2009, Hooft et al. 2011). Las aflatoxinas son hidrocarburos aromáticos policíclicos, producidos principalmente por Aspergillus flavus y Aspergillus parasiticus y en menor medida por Aspergillus nominus. Las aflatoxinas que comúnmente se encuentran en los alimentos son la aflatoxina B1 (AFB1), la aflatoxina B2 (AFB2), la aflatoxina G1 (AFG1) y la aflatoxina G2 (AFG2) (Ottinger y Kaattari 1998, 2000; Huang et al. 2011). Estas micotoxinas se encuentran principalmente en áreas tropicales y subtropicales y contaminan alimentos con alto contenido de almidón y lípidos, como semilla de algodón, maíz, maní, trigo y soja (OstrowskiMeissner et al. 1995).

Entre las aflatoxinas, la AFB1 se considera el carcinógeno más potente, clasificado en el grupo 1 por la Agencia Internacional para la Investigación del Cáncer (IARC 1993) y como altamente hepatocarcinogénico (Busby y Wogan 1984, Sharma y Salunkhe 1991, Miller y Trenholm 1994, Wang et al. 1998).

Se piensa que la toxicidad y carcinogenicidad de la AFB1 está directamente relacionada con su bioactivación. Después de ser ingerida, la AFB1 es transformada en el hígado en AFB1-8,9-epóxido (AFBO), un metabolito altamente reactivo. Esta bioactivación sucede principalmente por una una epoxidación del anillo funaro terminal de la AFB1 dependiente del citocromo P450 microsomal (CYP450) y es responsable de su fijación a macromoléculas celulares como el ADN, ARN y otros componentes proteicos (Massey et al. 1995, Smith et al. 1997, Wang y Groopman 1999). Esto resultará en la lesión o necrosis de hepatocitos y otras células metabólicamente activas, lo cual provocará una reducción del peso corporal, anormalidades conductuales, amarillamiento de la superficie corporal e inmunosupresión (Jantrarotai y Lovell 1990, Chávez-Sánchez et al. 1994, Eaton y Groopman 1994, Sahoo y Mukherjee 2001, Manning et al. 2005, Deng et al. 2010).

Se han realizado varios estudios sobre la toxicidad de la AFB1 en peces y crustáceos cultivados, incluyendo la trucha 
et al. 2014); channel catfish, Ictalurus punctatus (Plumb et al. 1986, Jantrarotai and Lovell 1990, Gallagher and Eaton 1995, Lumlertdacha et al. 1995, Manning et al. 2005); Nile tilapia, Oreochromis niloticus (Chávez-Sánchez et al. 1994, Anh Tuan et al. 2002, Deng et al. 2010, Hassan et al. 2010); rohu, Labeo rohita (Sahoo and Mukherjee 2001); seabass, Dicentrarchus labrax (El-Sayed and Khalil 2009, El-Sayed et al. 2009); gibel carp, Carassius auratus gibelio (Huang et al. 2011); and shrimps (Ostrowski-Meissner et al. 1995, Burgos-Hernández et al. 2005).

Several methods have been tested in an attempt to decrease the bioavailability of aflatoxin. The addition of mycotoxin binders to contaminated diets has been considered the most promising dietary approach to reduce effects of some mycotoxins (Galvano et al. 1996, 2001). Binders decontaminate aflatoxins by binding them strongly enough to prevent toxic interactions with the animal and to prevent mycotoxin absorption across the digestive tract. Several potential adsorbent materials have been tested, including activated carbon, aluminosilicates (clay, bentonite, montmorillonite, zeolite, phyllosilicates, etc.), complex indigestible carbohydrates (cellulose, polysaccharides from cell walls of yeast and bacteria such as glucomannans and peptidoglycans, and others), and synthetic polymers such as cholestryamine and polyvinylpyrrolidone and derivatives. However, their binding efficacy strongly differs according to the specific binder, its source, and the chemical structure of the mycotoxin. Additionally, some binders can have negative effects on growth due to their influence on nutrient utilization and mineral absorption (Chestnut et al. 1992, Kubena et al. 1993).

The yellow catfish, Pelteobagrus fulvidraco, is an important commercial species in China. This teleost fish species belongs to the order Siluriformes and has a high market value (Tan et al. 2009, Luo et al. 2011); however, as it is an omnivorous freshwater fish from a subtropical area, the probability of being affected by aflatoxin contaminated feedstuffs is large. Therefore, the objectives of this study were to investigate the sensitivity of yellow catfish to dietary AFB1 contamination, and to evaluate the efficiency of an aflatoxin binder in offsetting the negative effects of AFB1.

\section{MATERIALS AND METHODS}

\section{Experimental conditions}

Yellow catfish weighing $2.02 \pm 0.10 \mathrm{~g}$ (mean $\pm \mathrm{SD}$ ) each were obtained from a local commercial fish hatchery and transported to the experimental facilities. Prior to the start of the experiment, the fish were stocked in net cages $(3.0 \times$ $3.0 \times 3.0 \mathrm{~m}$ ), and fed the control diet for 2 weeks in order to acclimate to the experimental diet and facility conditions.

At the start of the experiment, fish were fasted for $24 \mathrm{~h}$ and weighed after being anesthetized. Fish with similar sizes were randomly distributed into 24 net cages $(2.0 \times 2.0 \times$ arcoiris, Oncorhynchus mykiss (Ngethe et al. 1993; Bailey et al. 1994; Ottinger y Kaattari 1998, 2000; Carlson et al. 2001; Hooft et al. 2011; Hanson et al. 2014); el bagre de canal, Ictalurus punctatus (Plumb et al. 1986, Jantrarotai y Lovell 1990, Gallagher y Eaton 1995, Lumlertdacha et al. 1995, Manning et al. 2005); la tilapia del Nilo, Oreochromis niloticus (Chávez-Sánchez et al. 1994, Anh Tuan et al. 2002, Deng et al. 2010, Hassan et al. 2010); el rohu, Labeo rohita (Sahoo y Mukherjee 2001); el róbalo, Dicentrarchus labrax (El-Sayed y Khalil 2009, El-Sayed et al. 2009); la carpa dorada, Carassius auratus gibelio (Huang et al. 2011); y camarones (Ostrowski-Meissner et al. 1995, BurgosHernández et al. 2005).

Varios métodos han sido probados en un intento por reducir la biodisponibilidad de la aflatoxina. La incorporación de captadores de micotoxinas a dietas contaminadas parece ser la estrategia más prometedora para disminuir los efectos de algunas micotoxinas (Galvano et al. 1996, 2001). Los captadores descontaminan las aflatoxinas al fijarlas lo suficiente para prevenir interacciones tóxicas con el animal y evitar la absorción de micotoxinas en el tracto digestivo. Se han probado diversos materiales adsorbentes, incluyendo carbón activado, aluminosilicatos (arcilla, bentonita, montmorillonita, zeolita, filosilicatos, etc.), carbohidratos complejos indigeribles (celulosa, polisacáridos de las paredes celulares de levaduras y bacterias como glucomanos y peptidoglicanos, entre otros) y polímeros sintéticos tales como la colestiramina y polivinilpirrolidona y sus derivados. No obstante, su capacidad de adsorción difiere fuertemente según el captador específico, su fuente y la estructura química de la micotoxina. Además, algunos captadores pueden tener un efecto negativo sobre el crecimiento debido a que afectan el uso de nutrientes y la absorción de minerales (Chestnut et al. 1992, Kubena et al. 1993).

El bagre amarillo, Pelteobagrus fulvidraco, es una especie de importancia comercial en China. Este pez teleósteo pertenece al orden Siluriformes y tiene un alto valor en el mercado (Tan et al. 2009, Luo et al. 2011); sin embargo, al ser un pez omnívoro de agua dulce de una zona subtropical, la probabilidad de que resulte afectado por alimento contaminado con aflatoxinas es alta. Por lo tanto, el objetivo de este estudio fue investigar la sensibilidad del bagre amarillo a la contaminación por AFB1 y evaluar la capacidad de un aglutinante de aflatoxinas para contrarrestar los efectos negativos de la AFB1.

\section{MATERIALES Y MÉTODOS}

\section{Condiciones experimentales}

Se obtuvieron ejemplares de P. fulvidraco con un peso promedio de $2.02 \pm 0.10 \mathrm{~g}$ ( \pm desviación estándar) de un criadero de peces comercial y se transportaron a las instalaciones experimentales. Antes de comenzar el experimento, los peces fueron colocados en jaulas de red $(3.0 \times 3.0 \times 3.0 \mathrm{~m})$ y 
$2.0 \mathrm{~m})$. Each cage was stocked with 40 fish. Fish were randomly hand-fed to apparent satiation twice a day (08:00 and 17:00) for approximately $5 \mathrm{~min}$ in each cage. As a voracious species, all feed given was estimated to be the same as eaten. No feed rejection, due to mycotoxin content, was observed. The feeding trial lasted for 12 weeks. The amount of feed given was adjusted every two weeks, according to fish growth (10 fish were bulk weighed), mortality, and feed conversion rate. Feeding was maintained equivalent between treatments with different survival rates. Water parameters (temperature, $28 \pm 1{ }^{\circ} \mathrm{C}$; dissolved oxygen, $5 \pm 0.5 \mathrm{mg} / \mathrm{L}$; $\mathrm{NO}_{3}-\mathrm{N}, 0 \pm 0.2 \mathrm{mg} / \mathrm{L}$; and $\mathrm{NO}_{2}-\mathrm{N}, 0 \pm 0.1 \mathrm{mg} / \mathrm{L}$ ) were checked daily and a natural photoperiod was provided.

\section{Preparation of experimental diets}

A basal diet was prepared using fish meal and soybean meal as main protein sources. Formulation and proximate chemical composition of the basal diet (\%) are listed in Table 1. Eight experimental diets were then prepared and the basal diet was spiked with different concentrations of pure AFB1 with or without the addition of an aflatoxin binder (Mycofix Secure). The four treatments with AFB1 were named A-0, A-2, A-5, and A-10, and contained 0, 200, 500, and $1,000 \mu \mathrm{g} / \mathrm{kg}$ of $\mathrm{AFB} 1$, respectively. The treatments with Mycofix Secure were named A-0M, A-2M, A-5M, and A-10M, and contained $0,200,500$, and $1,000 \mu \mathrm{g} / \mathrm{kg}$ of

Table 1. Formulation and proximate chemical composition of the basal diet (\%).

Tabla 1. Formulación y composición química proximal de la dieta basal (\%).

\begin{tabular}{lc}
\hline Ingredient & Quantity (\%) \\
\hline Fish meal & 35.00 \\
Soybean meal & 20.00 \\
Yeast powder & 5.00 \\
Rapeseed meal & 5.00 \\
Cotton meal & 5.00 \\
Wheat meal & 21.82 \\
Soybean oil & 3.00 \\
Mineral mixture & 3.00 \\
Vitamin mixture & 2.00 \\
Choline chloride & 0.10 \\
Ethoxyquin & 0.06 \\
Mold inhibitors & 0.02 \\
\hline Proximate chemical composition (\% dry matter) & \\
\hline Crude protein & 48.47 \\
Crude lipid & 6.12 \\
Crude ash & 10.80 \\
Moisture & 11.30 \\
\hline
\end{tabular}

alimentados con una dieta control durante 2 semanas para aclimatarlos a la dieta y a las condiciones experimentales.

Al inicio del experimento, los peces se mantuvieron en inanición durante $24 \mathrm{~h}$ y fueron pesados después de ser anestesiados. Ejemplares de tamaño similar fueron distribuidos aleatoriamente en 24 jaulas de red $(2.0 \times 2.0 \times 2.0 \mathrm{~m})$. En cada jaula se colocaron 40 peces. Los individuos fueron alimentados manualmente, al azar, a saciedad aparente dos veces al día (08:00 y 17:00) durante aproximadamente $5 \mathrm{~min}$ por jaula. Siendo una especie voraz, se estimó que la cantidad de alimento proporcionado fue la cantidad ingerida. No se observó un rechazo del alimento debido al contenido de micotoxinas. El experimento duró 12 semanas. Se ajustó la cantidad de alimento proporcionado cada 2 semanas, según el crecimiento de los individuos (pesando 10 peces en conjunto), la mortalidad y la tasa de conversión alimenticia. La alimentación se mantuvo equivalente entre los tratamientos con diferentes tasas de supervivencia. Los parámetros del agua (temperatura, $28 \pm 1{ }^{\circ} \mathrm{C}$; oxígeno disuelto, $5 \pm 0.5 \mathrm{mg} / \mathrm{L}$; $\mathrm{NO}_{3}-\mathrm{N}, 0 \pm 0.2 \mathrm{mg} / \mathrm{L} ;$ y $\mathrm{NO}_{2}-\mathrm{N}, 0 \pm 0.1 \mathrm{mg} / \mathrm{L}$ ) fueron monitoreados diariamente y se proporcionó un fotoperiodo natural.

\section{Preparación de las dietas experimentales}

Se preparó una dieta basal con harina de pescado y harina de soja como las principales fuentes de proteína. La formulación y la composición química proximal de la dieta basal (\%) se muestran en la Tabla 1. Luego se prepararon ocho dietas experimentales. A la dieta basal se añadieron diferentes concentraciones de AFB1 pura, con o sin la adición de un aglutinante de aflatoxinas (Mycofix Secure). Los cuatro tratamientos con AFB1 se llamaron A-0, A-2, A-5 y A-10, y se les adicionó 0, 200, 500 y 1,000 $\mu \mathrm{g} / \mathrm{kg}$ de AFB1, respectivamente. Los tratamientos con Mycofix Secure se llamaron A-0M, A-2M, A-5M y A-10M, y se les adicionó 0 , 200,500 y $1,000 \mu \mathrm{g} / \mathrm{kg}$ de AFB1, respectivamente, más $0.2 \%$ de Mycofix Secure en cada dieta (nivel de inclusión recomendada por BIOMIN).

La AFB1 pura fue proporcionada por BIOMIN Co. Ltd. (China). La concentración de micotoxinas en las dietas fue analizada mediante cromatografía líquida de alta resolución (HPLC por sus siglas en inglés). Mycofix Secure (BIOMIN Holding $\mathrm{GmbH}$, Austria) es una bentonita (montmorillonita dioctaédrica), comercializada como un aditivo alimenticio para acuicultura, con propiedades aglutinantes.

Los ingredientes se molieron y tamizaron en una malla de $250 \mu \mathrm{m}$ hasta obtener un polvo fino. Todos los ingredientes fueron mezclados con aceite de pescado y se añadió agua para obtener una masa firme. La masa se pasó por un molino de alimentos (F-26(II), Universidad de Tecnología del Sur de China) y se secó en un horno ventilado a $40{ }^{\circ} \mathrm{C}$, después del cual se cortó en trozos (pellets) de $2.0 \times 5.0 \mathrm{~mm}$. El alimento se almacenó a $-20^{\circ} \mathrm{C}$ hasta usarse. En la Tabla 2 se muestran las cantidades de AFB1 y Mycofix Secure usadas, y la 
AFB1, respectively, plus $0.2 \%$ of Mycofix Secure in each diet (BIOMIN recommended inclusion level).

Pure AFB1 was provided by BIOMIN Co. Ltd. (China), and the concentration of mycotoxins in the diets was analyzed by high-performance liquid chromatography (HPLC). Mycofix Secure (BIOMIN Holding GmbH, Austria) is a bentonite (dioctahedral montmorillonite) commercialized as feed additive for aquaculture, with aflatoxin-binding properties.

Ingredients were ground into fine powder through a $250 \mu \mathrm{m}$ mesh. All ingredients were mixed with fish oil and water was added to produce a stiff dough. The dough was then pelleted with an experimental feed mill (F-26(II), South China University of Technology, China) and dried in a ventilated oven at $40{ }^{\circ} \mathrm{C}$. After drying, diets were broken up and cut into $2.0 \times 5.0 \mathrm{~mm}$ pellets. Diets were stored at $-20^{\circ} \mathrm{C}$ until use. The amounts of AFB1 and Mycofix Secure, and the proximate composition of the experimental diets after addition of AFB1 are given in Table 2.

\section{Growth performance}

Feed consumption was recorded daily. At the end of the experiment, fish were counted and individually weighed to calculate the survival rate and weight gain. Specific growth rate (SGR) was calculated according to the formula SGR = $100(\ln W 2-\ln W 1) /(t 2-t 1)$, where $W 1$ and $W 2$ are the weights of the fish measured at times $t 1$ and $t 2$. The feed conversion ratio (FCR) for each treatment was calculated by the following equation: $\mathrm{FCR}=F /(W 2-W 1)$, where $F$ is the weight of food supplied to fish during the study period, $W 1$ is the live weight of fish at the beginning of the study period, and $W 2$ is the live weight of the fish at the end of the study period. The FCR was measured every 2 weeks; the FCR presented in the manuscript is an average of the 6 weeks of measurements. composición proximal de las dietas experimentales después de añadir la AFB1.

\section{Crecimiento}

El consumo de alimento se registró diariamente. Al final del experimento, los peces fueron contados y pesados individualmente para calcular la tasa de supervivencia y el aumento de peso. La tasa de crecimiento específico (TCE) se calculó mediante la siguiente ecuación: TCE = $100(\ln W 2-\ln W 1) /(t 2-t 1)$, donde $W 1$ y $W 2$ son los pesos de los individuos medidos en los tiempos $t 1$ y $t 2$. La tasa de conversión alimenticia (TCA) para cada tratamiento se calculó con la siguiente ecuación: TCA $=F /(W 2-W 1)$, donde $F$ es el peso del alimento proporcionado a los peces durante el periodo de estudio, $W 1$ es el peso vivo del individuo al inicio del periodo de estudio y $W 2$ es el peso vivo del individuo al final del periodo de estudio. La TCA se midió cada 2 semanas, y la TCA presentada en este manuscrito es un promedio de 6 semanas de mediciones.

\section{Muestras de sangre}

Al final del ensayo, se tomaron muestras de sangre de 10 peces. La sangre se tomó por la vena caudal y se dejó cuagular a tamperatura ambiente durante $4 \mathrm{~h}$. El suero fue retirado y congelado a $-80^{\circ} \mathrm{C}$ hasta usarse.

\section{Efectos inmunosupresores}

\section{Actividad bactericida}

Para estudiar la actividad bactericida se usaron alícuotas del suero recolectado (Kajita 1990). Las muestras de suero de cada grupo se juntaron en tres alícuotas y se diluyeron tres veces con tampón veronal con gelatina al $0.1 \%(\mathrm{GVB} 2+)$

Table 2. Summary of the amounts of aflatoxin 1 (AFB1) and Mycofix Secure and proximate composition of the experimental diets.

Tabla 2. Resumen de la cantidad de aflatoxina 1 (AFBI) y Mycofix Secure y la composición proximal de las dietas experimentales.

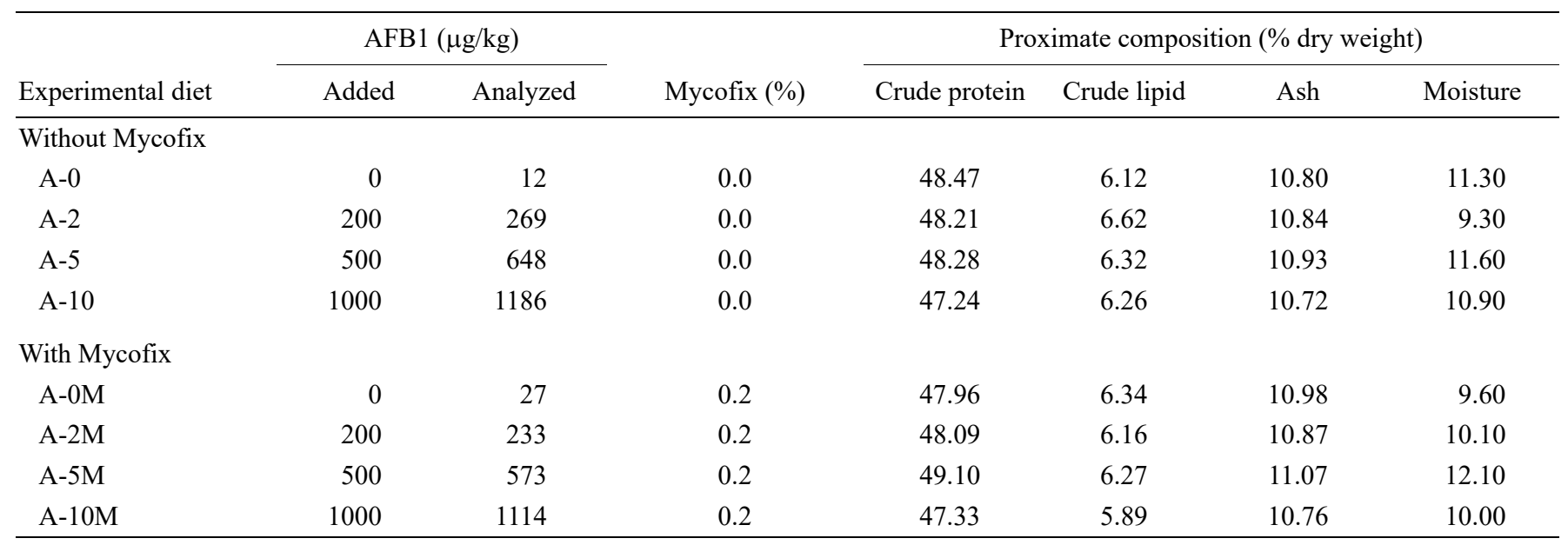




\section{Blood sampling}

At the end of the trial, 10 fish from each net cage were collected for blood samples. Blood was drawn from the caudal vein of the fish and was allowed to clot at room temperature for $4 \mathrm{~h}$. The serum was removed and frozen at $-80^{\circ} \mathrm{C}$ until use.

\section{Immunosuppressive effects}

\section{Bactericidal activity}

Aliquots of the collected serum were used to study bactericidal activity (Kajita 1990). Serum samples from each group were pooled into three aliquots and diluted three times with $0.1 \%$ gelatin veronal buffer $(\mathrm{GVB} 2+)$ ( $\mathrm{pH} \mathrm{7.5,} \mathrm{con-}$ taining $0.5 \mathrm{mM} \mathrm{mL}^{-1} \mathrm{Mg}^{2+}$ and $0.15 \mathrm{mM} \mathrm{mL}^{-1} \mathrm{Ca}^{2+}$ ). Live, washed bacterial cells of Edwardsiella tarda were suspended in the same buffer to $1 \times 10^{5} \mathrm{CFU}$ per milliliter. The diluted serum and bacteria were mixed at a proportion of $1: 1$, incubated for $90 \mathrm{~min}$ at $25^{\circ} \mathrm{C}$, and shaken. The number of viable bacteria was calculated by counting the colonies from the resultant incubated mixture on TSA plates, in duplicate, after $24 \mathrm{~h}$ of incubation.

\section{Albumin/globulin ratio}

The rest of the serum from the 10 fish of each cage was analyzed for the albumin/globulin (A:G) ratio (Sahoo et al. 1999). Serum samples were analyzed for total protein following the dye-binding method of Bradford (1976) and using bovine serum albumin as standard. Albumin was measured by the bromocresol green method and globulin by subtracting the albumin value from the total protein value. Finally, the A:G ratio was calculated.

\section{Lysozyme assay}

Lysozyme activity in serum of 5 fish from each cage was determined as described by Ellis (1990). Results were expressed in units of lysozyme per millimeter of serum. One unit is defined as the amount of sample causing a decrease in absorbance of $0.001 \mathrm{~min}^{-1}$ at $530 \mathrm{~nm}$ compared to the control (Micrococcus lysodeikticus suspension without serum).

\section{Alternative complement pathway activity}

Alternative complement pathway (ACP) activity was analyzed in serum of 5 fish per cage according to Yano (1996). Briefly, a series of volumes of the diluted serum ranging from 0.1 to $0.25 \mathrm{~mL}$ were dispensed into test tubes and the total volume made up to $0.25 \mathrm{~mL}$. Then, with barbitone buffer in the presence of ethylene glycol-bis (2-aminoethoxy)-tetraacetic acid (EGTA) and $\mathrm{Mg}^{2+}, 0.1 \mathrm{~mL}$ of rabbit red blood cells (RaRBC) was added to each tube. After
(pH 7.5, con $0.5 \mathrm{mM} \mathrm{mL}^{-1} \mathrm{Mg}^{2+}$ y $0.15 \mathrm{mM} \mathrm{mL}^{-1} \mathrm{Ca}^{2+}$ ). Células vivas y lavadas de la bacteria Edwardsiella tarda fueron suspendidas en la misma solución a una concentración de $1 \times 10^{5}$ UFC por mililitro. El suero diluido y las bacterias se mezclaron a una proporción de 1:1, y la mezcla se incubó durante 90 min a $25^{\circ} \mathrm{C}$ y se agitó. Para calcular el número de bacterias viables se contaron las colonias de la mezcla incubada en placas de TSA, por duplicado, después de $24 \mathrm{~h}$ de incubación.

\section{Relación albúmina/globulina}

El suero restante de los 10 peces de cada jaula fue analizado para evaluar la relación albúmina/globulina (A:G) (Sahoo et al. 1999). Se analizaron las muestras de suero para determinar la proteína total según el método de fijación de colorantes de Bradford (1976) con albúmina de suero bovino como estándar. La albúmina se midió mediante el método de verde de bromocresol y la globulina restando el valor de la albúmina del valor de la proteína total, y se calculó la relación $\mathrm{A}: \mathrm{G}$.

\section{Actividad de la lisozima}

La actividad de la lisozima en el suero de 5 peces de cada jaula se determinó según Ellis (1990). Los resultados se expresan en unidades de lisozima por milímetro de suero. Una unidad se define como la cantidad de muestra que causa una disminución de la absorbancia de $0.001 \mathrm{~min}^{-1}$ a $530 \mathrm{~nm}$ en comparación con el control (suspensión de Micrococcus lysodeikticus sin suero).

\section{Actividad de la vía alternativa del complemento}

Se analizó la actividad de la vía alternativa del complemento en el suero de 5 peces de cada jaula según Yano (1996). Brevemente, primero se introdujeron diferentes volúmenes, de 0.1 a $0.25 \mathrm{~mL}$, del suero diluido en tubos de ensayo, y el volumen total fue de $0.25 \mathrm{~mL}$. Luego, con un tampón de barbitona en presencia de ácido etilenglicol tetraacético (EGTA) y $\mathrm{Mg}^{2+}$, se añadieron $0.1 \mathrm{~mL}$ de células rojas de la sangre de conejo a cada tubo. Después de incubar durante $2 \mathrm{~h}$ a $22^{\circ} \mathrm{C}$, se añadieron $3.15 \mathrm{~mL}$ de $\mathrm{NaCl}$ al $0.9 \%$. Posteriormente, la muestra se centrifugó a $836 \times g$ durante 5 min a $4{ }^{\circ} \mathrm{C}$ para eliminar las células rojas no lisadas. La densidad óptica del sobrenadante se midió a $414 \mathrm{~nm}$. Se determinó el volumen de suero que produce el 50\% de hemólisis (ACH50) y se obtuvo el número de unidades de ACH50 por milímetro para cada grupo.

\section{Parámetros patológicos del suero}

Se analizaron la transaminasa glutámico-pirúvica (GPT), la transaminasa glutámico-oxalacética (GOT), el nitrógeno ureico en sangre (BUN) y el ácido úrico mediante sus 
Wang et al.: Influence of aflatoxin B1 on yellow catfish (Pelteobagrus fulvidraco)

incubation during $2 \mathrm{~h}$ at $22{ }^{\circ} \mathrm{C}, 3.15 \mathrm{~mL}$ of $0.9 \% \mathrm{NaCl}$ was added. Following this, the sample was centrifuged at $836 \times g$ for $5 \mathrm{~min}$ at $4^{\circ} \mathrm{C}$ to eliminate unlysed RaRBC. The optical density of the supernatant was measured at $414 \mathrm{~nm}$. The volume of serum producing $50 \%$ hemolysis $(\mathrm{ACH} 50)$ was determined and the number of ACH50 units per milliliter was obtained for each group.

\section{Serum pathology parameters}

Glutamic-pyruvic transaminase (GPT), glutamic-oxaloacetic transaminase (GOT), blood urea nitrogen (BUN), and uric acid were analyzed using the respective assay kit (Nanjing Jiancheng Bioengineering Institute, China).

\section{Mycotoxin analysis}

Feed samples were collected according to Richard (2000). The analyses were carried out as described by Binder et al. (2007). All samples were analyzed with HPLC. For the purpose of data analysis, non-detect levels are based on the limits of detection of the HPLC. For AFB1, AFB2, $\mathrm{AFG} 1$, and AFG2, the detection limits are 0.3, 0.1, 0.1, and $0.1 \mu \mathrm{g} / \mathrm{kg}$, respectively.

\section{Statistical analysis}

All data were subjected to analysis of variance in SPSS 19.0 for Windows. One-way ANOVA was performed and differences between the means were tested by Tukey's multiple range test. Additionally, a two-way ANOVA was performed to analyze the effects of the binder and AFB1 concentration on the response variables. The level of significance was chosen at $P<0.05$ and the results are presented as mean $\pm \mathrm{SD}$ (standard deviation of the mean).

\section{RESULTS}

\section{Growth performance and survival}

Feed analysis showed that AFB1 contamination was successfully achieved although observed levels were higher than expected (Table 2).

Results after the 12-week feeding trial showed that yellow catfish are sensitive to AFB1 contamination in the feed. The presence of AFB1 in the diet at levels of $500 \mu \mathrm{g} / \mathrm{kg}$ or higher led to a significant $(P=0.014)$ increase in FCR. There was also a statistical significant interaction between binder and AFB1 in the $\operatorname{diet}(P=0.019)$, representing a less accentuated increase in FCR when using the binder in the diet (Fig. 1). Survival decreased significantly $(P=0.002)$ with the increase of AFB1 in the diet; however, Mycofix had no effect on this parameter $(P=0.093)$. Although there was no statistical difference in binder efficacy, when the diet contained $1,000 \mu \mathrm{g} / \mathrm{kg}$ of AFB1, survival was reduced $22 \%$ in the A- 10 respectivos kits de ensayo (Instituto de Bioingenería de Nanjing Jiancheng, China).

\section{Análisis de micotoxinas}

Se recolectaron muestras de alimento según Richard (2000). Los análisis fueron realizados según lo descrito por Binder et al. (2007). Todas las muestras se analizaron mediante HPLC. Para el análisis de los datos, los niveles no detectables se basan en los límites de detection de HPLC. Para AFB1, AFB2, AFG1 y AFG2, los límites de detección son $0.3,0.1,0.1$ y $0.1 \mu \mathrm{g} / \mathrm{kg}$, respectivamente.

\section{Análisis estadísticos}

Todos los datos fueron sometidos a análisis de varianza en SPSS 19.0 para Windows. Se realizó un análisis de varianza de una vía y se examinaron las diferencias entre las medias mediante la prueba de rangos múltiples de Tukey. Además, se realizó un análisis de varianza de dos vías para analizar los efectos del aglutinante y la concentración de AFB1 sobre las variables de respuesta. El nivel de significación se estableció en $P<0.05$ y los resultados se presentan como la media $\pm \mathrm{DE}$ (desviación estándar de la media).

\section{Resultados}

\section{Crecimiento y supervivencia}

El experimento mostró que la contaminación por AFB1 se logró éxitosamente, aunque los niveles observados fueron superiores a los esperados (Tabla 2).

Los resultados obtenidos después de 12 semanas de experimentación indicaron que $P$. fulvidraco es susceptible a contaminación por la AFB1 en el alimento. La presencia de AFB1 en la dieta a niveles de $500 \mu \mathrm{g} / \mathrm{kg}$ o mayores resultó en un aumento significativo $(P=0.014)$ de la TCA. También se observó una interacción estadística significativa entre la bentonita (Mycofix Secure) y la AFB1 en la dieta $(P=0.019)$, con menor aumento de la TCA cuando se usó el aglomerante en la dieta (Fig. 1). La supervivencia disminuyó significativamente $(P=0.002)$ al aumentar el nivel de AFB1 en la dieta; sin embargo, la bentonita no tuvo un efecto sobre este parámetro $(P=0.093)$. A pesar de que no se encontró una diferencia estadística en la capacidad del aglomerante, cuando los peces fueron alimentados con la dieta A-10 que contenía $1,000 \mu \mathrm{g} / \mathrm{kg}$ de AFB1, la supervivencia disminuyó $22 \%$, mientras que en el tratamiento equivalente (A-10M) que contenía la bentonita, la supervivencia sólo disminuyó $13.5 \%$, en comparación con el grupo control (Tabla 3).

El crecimiento también fue afectado por la AFB1 a niveles de $200 \mu \mathrm{g} / \mathrm{kg}$ o mayores (Tabla 3). Se observó una relación negativa entre la presencia de AFB1 en la dieta y el crecimiento de los peces (aumento de peso, TCE); sin embargo, esta respuesta negative fue menos pronunciada 
treatment, while in the equivalent treatment with the binder, A-10M, survival was reduced only $13.5 \%$, when compared with the control group (Table 3).

Growth performance was also affected by AFB1 at levels of $200 \mu \mathrm{g} / \mathrm{kg}$ or higher (Table 3). A negative relationship between the presence of AFB1 in the diet and fish growth performance (weight gain, SGR) was observed; however, this negative response was less pronounced when the aflatoxin binder was supplemented to the contaminated feed (Table 3 ). As observed for growth performance and survival rate, the negative impact of AFB1 on fish fed diets supplemented with the binder was less pronounced.

\section{Proximate carcass composition of fish}

Regarding carcass composition of fish, no significant differences were found between treatments (Table 4).

\section{Serum immunological parameters}

Table 5 shows a summary of serum immunological parameters (bactericidal activity [number of bacterial colonies], A:G ratio, lysozyme, ACP, and total protein) for yellow catfish fed the experimental diets for 12 weeks. It is clear that the presence of AFB1 in the diets affected these parameters, with the exception of ACP for which no significant differences between the diets were found. For the bactericidal activity, the higher the amount of AFB1 in the diets, the higher the number of bacterial colonies counted $(P=$ 0.001). As such, the number of bacterial colonies in A-10 was significantly higher $(P=0.001)$ when comparing diets A-0 and A- $0 \mathrm{M}$. The A:G ratio had a similar pattern to that of the number of bacterial colonies, with A-10 presenting the highest A:G ratio and A-0 and A- $0 \mathrm{M}$ the lowest. Values for lysozyme and total protein decreased throughout the treatments with the increase in AFB1 concentration. Groups supplemented with Mycofix had less pronounced reduction compared to non-supplemented ones, but no significant statistical effect of the binder was detected.

\section{Serum pathological parameters}

Fish displayed no significant differences in BUN and uric acid among all treatments, although A-10 tended to have higher values when compared with the other diets. There was a significant increase in GPT $(P=0.002)$ and GOT $(P<0.001)$ with the increase of AFB1 in the diets. In the Mycofix treated groups, GPT values showed no difference between treatments; however, GOT levels significantly increased $(P=0.026)$ with the increase of aflatoxin levels in the diets (Table 6).

\section{DISCUSSION}

The levels of AFB1 obtained in the experimental diets were higher than expected, and this is linked to natural

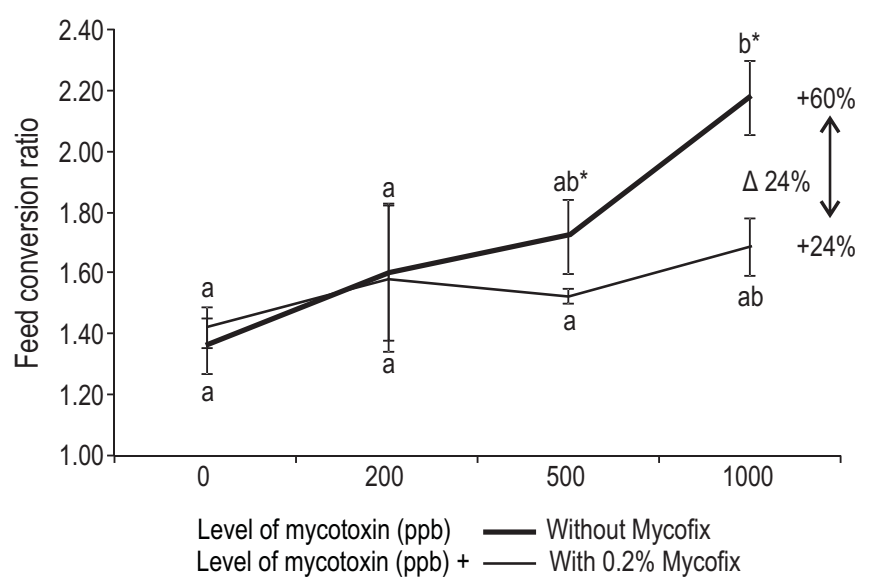

Figure 1. Effect of dietary aflatoxin B1 (AFB1) on feed conversion ratio during the experimental trial (12 weeks). Significant differences were found regarding the efficacy of Mycofix Secure offsetting the negative effects of AFB1 (diet*binder $P=0.019)$. Differences were also found for the level of mycotoxin in the diet $(P<0.001)$ and the binder $(P=0.014)$. Superscript letters show differences for the mycotoxin level and the asterisks indicate differences in the efficacy of the binder. Points sharing the same superscript letter are not significantly different according to Tukey's honestly significant difference. Data are presented as mean \pm standard deviation.

Figura 1. Efecto de la aflaxotina B1 (AFB1) en la dieta sobre la tasa de conversión alimenticia durante el experimento (12 semanas). Se encontraron diferencias significativas en la eficacia de Mycofix Secure para contrarrestar los efectos negativos de la AFB1 (dieta*aglutinante $P=0.019$ ). También se encontraron diferencias en cuanto al nivel de la micotoxina en la dieta $(P<0.001)$ y el aglutinante $(P=0.014)$. Las letras minúsculas indican diferencias en el nivel de la micotoxina y los asteriscos indican diferencias en la eficacia del aglutinante. Los puntos que muestran la misma letra no son significativamente diferentes según la diferencia honestamente significativa de Tukey. Los datos se presentan como la media \pm desviación estándar.

cuando se adicionó la bentonita a las dietas contaminadas (Tabla 3). Tanto para el crecimiento como la tasa de supervivencia, el efecto negativo de la AFB1 sobre los peces alimentados con dietas suplementadas con la bentonita fue menos pronunciado.

\section{Composición proximal del cuerpo de los peces}

En cuanto a la composición proximal del cuerpo de los peces, no se encontraron diferencias significativas entre los tratamientos (Tabla 4).

\section{Parámetros inmunológicos del suero}

En la Tabla 5 se muestran los valores de los parámetros inmunológicos del suero (actividad bactericida [número de colonias bacterianas], lisozima, relación A:G, vía alternativa 
Wang et al.: Influence of aflatoxin B1 on yellow catfish (Pelteobagrus fulvidraco)

Table 3. Summary of growth parameters for yellow catfish during the experimental period.

Tabla 3. Resumen de los parámetros de crecimiento del bagre amarillo durante el periodo experimental.

\begin{tabular}{|c|c|c|c|c|c|}
\hline Experimental diet & $\begin{array}{l}\text { Initial body weight } \\
\text { (g) }\end{array}$ & $\begin{array}{l}\text { Final body weight } \\
(\mathrm{g})\end{array}$ & Weight gain & $\begin{array}{c}\text { Specific growth rate } \\
\text { (\% day) }\end{array}$ & $\begin{array}{c}\text { Survival } \\
(\%)\end{array}$ \\
\hline \multicolumn{6}{|l|}{ Without Mycofix } \\
\hline A-2 & $1.97 \pm 0.03$ & $42.19 \pm 2.97^{\mathrm{ab}}$ & $40.22 \pm 2.98^{\mathrm{ab}}$ & 3.65 & $85.0 \pm 6.6$ \\
\hline A-5 & $2.05 \pm 0.13$ & $40.42 \pm 0.54^{\mathrm{ab}}$ & $38.37 \pm 0.55^{\mathrm{ab}}$ & 3.55 & $82.5 \pm 6.6$ \\
\hline \multicolumn{6}{|l|}{ With Mycofix } \\
\hline A- $0 \mathrm{M}$ & $2.13 \pm 0.11$ & $43.61 \pm 1.60^{\mathrm{a}}$ & $41.49 \pm 1.71^{\mathrm{a}}$ & 3.59 & $96.7 \pm 1.4$ \\
\hline A-2M & $1.98 \pm 0.15$ & $42.59 \pm 2.28^{\mathrm{ab}}$ & $40.62 \pm 2.40^{\mathrm{ab}}$ & 3.65 & $89.2 \pm 6.3$ \\
\hline A-5M & $2.00 \pm 0.11$ & $42.08 \pm 0.48^{\mathrm{ab}}$ & $40.08 \pm 0.37^{\mathrm{ab}}$ & 3.63 & $88.3 \pm 1.4$ \\
\hline Binder & NS & 0.038 & 0.046 & 0.485 & 0.093 \\
\hline Diet*Binder & NS & 0.616 & 0.654 & 0.834 & 0.519 \\
\hline
\end{tabular}

Data are presented as mean \pm SD. Values in the same column with different letters are significantly different $(P<0.05)$. NS $=$ not significant.

Table 4. Proximate carcass composition of yellow catfish fed experimental diets for 12 weeks.

Tabla 4. Composición proximal del cuerpo del bagre amarillo alimentado con dietas experimentales durante 12 semanas.

\begin{tabular}{|c|c|c|c|c|}
\hline Experimental diet & Crude protein $(\%)$ & Crude lipid (\%) & Moisture (\%) & Ash (\%) \\
\hline A-0 & $14.35 \pm 0.46$ & $7.90 \pm 0.57$ & $73.70 \pm 0.91$ & $3.31 \pm 0.13$ \\
\hline A-5 & $14.76 \pm 0.52$ & $8.28 \pm 0.01$ & $72.51 \pm 1.15$ & $3.44 \pm 0.06$ \\
\hline A-10 & $13.79 \pm 1.73$ & $7.04 \pm 0.34$ & $72.21 \pm 2.73$ & $3.18 \pm 0.39$ \\
\hline A-0M & $15.66 \pm 2.48$ & $8.59 \pm 0.11$ & $71.18 \pm 3.22$ & $3.53 \pm 0.52$ \\
\hline A-2M & $13.99 \pm 0.46$ & $8.21 \pm 0.58$ & $73.97 \pm 0.95$ & $3.29 \pm 0.31$ \\
\hline$A-5 \mathrm{M}$ & $12.58 \pm 1.58$ & $6.78 \pm 0.80$ & $76.54 \pm 2.90$ & $2.87 \pm 0.49$ \\
\hline A-10M & $14.56 \pm 0.38$ & $8.82 \pm 0.47$ & $72.08 \pm 1.20$ & $3.55 \pm 0.21$ \\
\hline
\end{tabular}

contamination of ingredients used in the basal diets (12 and $27 \mu \mathrm{g} / \mathrm{kg}$ for diets $\mathrm{A}-0$ and A-0M, respectively). This fact highlights the risk of AFB1 contamination in feedstuffs used in aquafeeds. It is well known that some plant sources used in aquaculture feeds, especially in subtropical and tropical areas, have a high risk of aflatoxin contamination, which adversely affects fish health and welfare, resulting in high production losses (Ciegler et al. 1981, Cole and Cox 1981, CAST 2003, McKean et al. 2006, Bryden 2011, Hooft et al. 2011).

Throughout the experimental period it was possible to confirm that the yellow catfish, $P$. fulvidraco, is sensitive to AFB1. Based on growth performance parameter results, levels of $200 \mu \mathrm{g} / \mathrm{kg}$ or higher of AFB1 in the diet are toxic to del complemento y proteína total) para los peces alimentados con las dietas experimentales durante 12 semanas. Es claro que la presencia de AFB1 en las dietas afectó estos parámetros, con excepción de la vía alternativa del complemento, que no mostró diferencias entre las dietas. En cuanto a la actividad bactericida, el número de colonias bacterianas aumentó conforme aumentó el nivel de AFB1 en las dietas $(P=0.001)$. El número de colonias bacterianas en $\mathrm{A}-10$ fue significativamente mayor $(P=0.001)$ que en las dietas $\mathrm{A}-0 \mathrm{y}$ A-0M. La relación A:G mostró un patrón similar, siendo mayor para A-10 y menor para A-0 y A-0M. Los valores para la lisozima y proteína total disminuyeron conforme aumentó el nivel de AFB1. La reducción fue menos pronunciada en los grupos que recibieron Mycofix en comparación con los 
Table 5. Serum immunological parameters of yellow catfish fed experimental diets for 12 weeks.

Tabla 5. Parámetros inmunológicos del suero del bagre amarillo alimentado con dietas experimentales durante 12 semanas.

\begin{tabular}{|c|c|c|c|c|c|}
\hline Experimental diet & $\begin{array}{c}\text { Bactericidal activity } \\
\text { (\# of bacterial colonies) }\end{array}$ & $\begin{array}{l}\text { Albumin/globulin } \\
\text { ratio }\end{array}$ & Lysozyme & $\begin{array}{c}\text { Alternative } \\
\text { complement pathway }\end{array}$ & $\begin{array}{l}\text { Total protein } \\
(\mathrm{g} / \mathrm{L})\end{array}$ \\
\hline \multicolumn{6}{|l|}{ Without Mycofix } \\
\hline $\mathrm{A}-0$ & $6.33 \pm 1.53^{\mathrm{a}}$ & $1.07 \pm 0.15^{\mathrm{b}}$ & $0.36 \pm 0.04^{\mathrm{a}}$ & $109.30 \pm 3.18$ & $32.05 \pm 1.23^{\mathrm{a}}$ \\
\hline A-2 & $7.67 \pm 1.15^{\mathrm{ab}}$ & $1.47 \pm 0.55^{\mathrm{ab}}$ & $0.30 \pm 0.05^{\mathrm{ab}}$ & $110.82 \pm 6.71$ & $31.47 \pm 1.41^{\mathrm{ab}}$ \\
\hline A-5 & $8.33 \pm 1.15^{\mathrm{ab}}$ & $1.63 \pm 0.15^{\mathrm{ab}}$ & $0.31 \pm 0.03^{\mathrm{ab}}$ & $105.41 \pm 3.06$ & $26.51 \pm 4.24^{\mathrm{ab}}$ \\
\hline A-10 & $11.67 \pm 1.53^{\mathrm{b}}$ & $2.20 \pm 0.26^{\mathrm{a}}$ & $0.23 \pm 0.02^{\mathrm{b}}$ & $103.36 \pm 5.44$ & $23.18 \pm 1.83^{b}$ \\
\hline \multicolumn{6}{|l|}{ With Mycofix } \\
\hline A-0M & $5.67 \pm 2.08^{\mathrm{a}}$ & $1.17 \pm 0.25^{b}$ & $0.35 \pm 0.06^{\mathrm{a}}$ & $112.89 \pm 7.77$ & $31.88 \pm 2.43^{\mathrm{a}}$ \\
\hline $\mathrm{A}-2 \mathrm{M}$ & $8.33 \pm 1.15^{\mathrm{ab}}$ & $1.37 \pm 0.50^{\mathrm{ab}}$ & $0.34 \pm 0.06^{\mathrm{a}}$ & $108.90 \pm 5.66$ & $31.12 \pm 5.04^{\mathrm{ab}}$ \\
\hline $\mathrm{A}-5 \mathrm{M}$ & $9.67 \pm 0.58^{\mathrm{ab}}$ & $1.73 \pm 0.35^{\mathrm{ab}}$ & $0.31 \pm 0.02^{\mathrm{ab}}$ & $106.15 \pm 3.03$ & $28.58 \pm 1.73^{\mathrm{ab}}$ \\
\hline A-10M & $9.33 \pm 2.08^{\mathrm{ab}}$ & $1.93 \pm 0.45^{\mathrm{ab}}$ & $0.30 \pm 0.01^{\mathrm{ab}}$ & $109.35 \pm 2.12$ & $26.34 \pm 3.67^{\mathrm{ab}}$ \\
\hline \multicolumn{6}{|c|}{ Two-way ANOVA $P$ value } \\
\hline Diet & 0.001 & 0.004 & 0.006 & NS & 0.002 \\
\hline Binder & 0.686 & 0.710 & 0.139 & NS & 0.351 \\
\hline Diet*Binder & 0.191 & 0.843 & 0.233 & NS & 0.694 \\
\hline
\end{tabular}

Data are presented as mean \pm SD. Values in the same column with different letter are significantly different $(P<0.05)$. NS $=$ not significant.

yellow catfish. Looking at other species, Deng et al. (2010) reported no significant differences in survival among tilapia exposed to AFB1 concentrations ranging from 19 to $1,641 \mu \mathrm{g} / \mathrm{kg}$ diet in a 20 -week trial. Tuan et al. (2002) also found no significant differences in tilapia survival when fish were fed levels of $10 \mathrm{mg}$ AFB1/kg, and Chávez-Sánchez et al. (1994) found the same conclusions at levels up to $30 \mathrm{mg}$ AFB $1 / \mathrm{kg}$. These data suggest that the yellow catfish is more sensitive to AFB1 than tilapia, which might be related to the respective feeding habits. Several authors (El-Banna et al. 1992, Zaki et al. 2008, Deng et al. 2010) have demonstrated that AFB1 exposure could cause adverse effects on growth performance of different fish species. Normally, a reduction in weight gain and increased FCR are observed (Jantrarotai and Lovell 1990, Deng et al. 2010, Huang et al. 2011) and confirmed by the present study on yellow catfish. Nonetheless, discrepancies between results, even for the same species, are considerable (Deng et al. 2010, Zychowski et al. 2013). For example, in a 20 -week trial using tilapia, Deng et al. (2010) showed that just after 15 weeks, fish exposed to $1,641 \mu \mathrm{g}$ AFB1/kg diet had significantly lower weight gain. However, Zychowski et al. (2013) concluded that AFB1 had a significant impact on tilapia over 10 weeks, with decreased weight gain and lower feed efficiency, at a lower level of AFB1 $(3 \mu \mathrm{g} / \mathrm{kg})$. These discrepancies can be attributed to differences in sex, age, and locality, or to different environmental or nutritional conditions (Eaton and Groopman 1994), and to exposure time which changes the way the animal copes with the toxin.

In the current study, the diets containing Mycofix Secure showed a tendency to decrease the negative effects on que no, pero no se detectó un efecto estadístico significativo del aglutinante.

\section{Parámetros patológicos del suero}

Los peces no mostraron diferencias significativas con respecto a BUN y ácido úrico entre los tratamientos, aunque A-10 generalmente presentó valores mayores en comparación con las otras dietas. Se observó un aumento significativo de GPT $(P=0.002)$ y GOT $(P<0.001)$ según aumentó el nivel de AFB1 en las dietas. En los tratamientos con Mycofix, los valores de GPT no mostraron diferencias entre los grupos; sin embargo, los niveles de GOT aumentaron significativamente $(P=0.026)$ conforme aumentaron los niveles de AFB1 en las dietas (Tabla 6).

\section{Discusión}

Los niveles de AFB1 en las dietas experimentales fueron mayores de lo esperado y esto se asocia con la contaminación natural de los ingredientes usados en la dieta basal (12 y $27 \mu \mathrm{g} / \mathrm{kg}$ para las dietas A-0 y A-0M, respectivamente). Este hecho realza el riesgo de la contaminación por AFB1 en alimentos acuícolas. Es bien conocido que algunas de las fuentes vegetales que se usan en alimentos para la acuicultura, especialmente en zonas tropicales y subtropicales, tienen un alto riesgo de contaminación por aflatoxinas, con efectos adversos para la salud y el bienestar de los peces y altas pérdidas de producción (Ciegler et al. 1981, Cole y Cox 1981, CAST 2003, McKean et al. 2006, Bryden 2011, Hooft et al. 2011). 
Wang et al.: Influence of aflatoxin B1 on yellow catfish (Pelteobagrus fulvidraco)

Table 6. Serum pathological parameters of yellow catfish fed experimental diets for 12 weeks.

Tabla 6. Parámetros patológicos del suero del bagre amarillo alimentado con dietas experimentales durante 12 semanas.

\begin{tabular}{|c|c|c|c|c|}
\hline Experimental diet & $\begin{array}{l}\text { Glutamic-pyruvic } \\
\text { transaminase }\end{array}$ & $\begin{array}{c}\text { Glutamic-oxaloacetic } \\
\text { transaminase }\end{array}$ & Blood urea nitrogen & Uric acid \\
\hline \multicolumn{5}{|l|}{ Without Mycofix } \\
\hline A-0 & $11.45 \pm 1.29^{\mathrm{a}}$ & $18.79 \pm 2.26^{\mathrm{bc}}$ & $2.53 \pm 0.36$ & $108.47 \pm 7.62$ \\
\hline A-2 & $11.54 \pm 1.66^{\mathrm{ab}}$ & $26.11 \pm 2.86^{\mathrm{ab}}$ & $2.50 \pm 0.39$ & $105.38 \pm 3.29$ \\
\hline A-5 & $14.62 \pm 2.27^{\mathrm{ab}}$ & $27.04 \pm 2.68^{\mathrm{ab}}$ & $2.62 \pm 0.09$ & $111.97 \pm 7.13$ \\
\hline A-10 & $16.80 \pm 1.88^{\mathrm{b}}$ & $29.87 \pm 2.30^{\mathrm{a}}$ & $3.13 \pm 0.67$ & $116.30 \pm 5.72$ \\
\hline \multicolumn{5}{|l|}{ With Mycofix } \\
\hline A- $0 \mathrm{M}$ & $11.28 \pm 1.53^{\mathrm{a}}$ & $17.06 \pm 1.97^{\mathrm{c}}$ & $2.71 \pm 0.46$ & $113.93 \pm 7.84$ \\
\hline A-2M & $12.23 \pm 2.41^{\mathrm{ab}}$ & $19.27 \pm 4.28^{\mathrm{bc}}$ & $2.56 \pm 0.72$ & $109.49 \pm 4.22$ \\
\hline A-5M & $13.30 \pm 2.41^{\mathrm{ab}}$ & $21.87 \pm 5.71^{\mathrm{ab}}$ & $2.66 \pm 0.66$ & $108.73 \pm 8.35$ \\
\hline A-10M & $15.26 \pm 1.17^{\mathrm{ab}}$ & $30.83 \pm 3.04^{\mathrm{a}}$ & $3.07 \pm 0.27$ & $107.74 \pm 3.09$ \\
\hline \multicolumn{5}{|c|}{ Two-way ANOVA $P$ value } \\
\hline Diet & 0.002 & $<0.001$ & NS & NS \\
\hline Binder & 0.474 & 0.026 & NS & NS \\
\hline Diet*Binder & 0.724 & 0.191 & NS & NS \\
\hline
\end{tabular}

Data are presented as mean \pm SD. Values in the same column with different letters are significantly different $(P<0.05)$. NS $=$ not significant.

survival and growth performance (weight gain, SGR, and FCR) when compared with the diets lacking the binder. The diets containing Mycofix showed a slower decrease in weight gain when compared with the diets without the binder. It is also very interesting to perceive an accentuated drop in weight gain, between 500 and $1,000 \mu \mathrm{g} / \mathrm{kg}$ of AFB1, suggesting that this is the level at which this species starts having difficulties coping with biological damage from the toxins. The presence of AFB1 in the diet negatively affected the FCR of yellow catfish. In the A-10M treatment Mycofix improved the FCR by $24 \%$ when compared with the respective treatment without the binder (A-10). In general, Mycofix allowed improvements in FCR when compared with the relative control group. While the differences are not statistically significant, from an economic perspective, the improvement obtained in FCR (e.g., $24 \%$ for $1,000 \mu \mathrm{g} / \mathrm{kg}$ of AFB1 level) represents genuine revenue for aquaculture producers.

AFB1 is also a potent immune modulator leading to the suppression of the immune system (Ottinger and Kaattari 1998) and consequently affecting the normal values of total protein, albumin, globulin, and A:G ratio. Abnormal levels of these proteins have been associated with hemolysis or increased breakdown of red blood cells and/or liver damage (Islam et al. 2004). The liver is responsible for clearing the blood of bilirubin, so liver damage can result in the pale yellow color presented by sick animals and described as a possible sympton of mycotoxicosis in fish. In our study, immunosuppression of catfish was confirmed from the reduced total protein and increased A:G ratio. Both globulin and albumin are produced by the liver and if the liver is damaged, it can no longer produce these proteins. So we can
A lo largo del periodo experimental fue posible confirmar que el bagre amarillo, P. fulvidraco, es susceptible a la AFB1. Los resultados de los parámetros de crecimiento muestran que niveles de $200 \mu \mathrm{g} / \mathrm{kg}$ o superiores de AFB1 en la dieta son tóxicos para esta especie. En comparación con otras especies, Deng et al. (2010) no encontraron diferencias significativas en la supervivencia de tilapias expuestas a concentraciones de AFB1 que variaron de 19 a $1,641 \mu \mathrm{g} / \mathrm{kg}$ en un experimento de 20 semanas. Tuan et al. (2002) tampoco encontraron diferencias significativas en la supervivencia de la tilapia del Nilo cuando los peces fueron alimentados con niveles de 10 mg AFB1/kg, y Chávez-Sánchez et al. (1994) obtuvieron las mismas conclusiones con niveles de hasta $30 \mathrm{mg} \mathrm{AFB} 1 / \mathrm{kg}$. Estos datos sugieren que el bagre amarillo es más susceptible a la AFB1 que la tilapia, lo cual puede estar relacionado con sus hábitos alimenticios. Varios autores (El-Banna et al. 1992, Zaki et al. 2008, Deng et al. 2010) han demostrado que el crecimiento de diferentes especies de peces puede resultar adversamente afectado por la exposición a AFB1. Normalmente se observan una reducción del aumento de peso y un aumento de la TCA (Jantrarotai y Lovell 1990, Deng et al. 2010, Huang et al. 2011), lo cual se confirma en el presente estudio. No obstante, las discrepancias entre los resultados, incluso para la misma especie, son considerables (Deng et al. 2010, Zychowski et al. 2013). Por ejemplo, en un experimento de 20 semanas con tilapias, Deng et al. (2010) encontraron que después de sólo 15 semanas los peces expuestos a $1,641 \mu \mathrm{g}$ AFB $1 / \mathrm{kg}$ dieta presentaron un aumento de peso significativamente menor. Por otro lado, Zychowski et al. (2013) encontraron que la AFB1 tuvo un efecto significativo sobre la tilapia durante 10 semanas, con 
conclude that the reduction in total protein level may be associated with liver and kidney disorders due to the ingestion of AFB1. The increased A:G ratio suggests underproduction of immunoglobulins, indicating a suppression of the fish immune system. Further, the immunosuppressive nature of AFB1 in yellow catfish can also be confirmed by the reduced bactericidal activity, which can be associated with the poor bacteria-destroying capacity of serum antimicrobial factors in fish fed the highest concentration of AFB1. In the case of the diets without Mycofix, the number of bacterial colonies in the A-10 diet was significantly higher than in the control treatment, showing a clear impact of AFB1 on serum antimicrobial factors. In general, values of fish ACP activity are considerably higher than those for mammals, suggesting that this activation pathway of the complement system is of particular relevance for fish as a non-specific immune mechanism (Yano et al. 1988, Sunyer and Tort 1995). In this study it was not possible to evaluate the relation between the AFB1 ingested and the ACP values.

Similarly to the ACP activity, fish lysozyme appears to be more active than that of higher vertebrates and is able to eliminate a variety of bacterial pathogens (Yousif et al. 1994). The innate immune system of fish is considered to be the main defense against a broad spectrum of pathogens and is more important for fish in comparison to mammals, with lysozyme activity being an important index of innate immunity of fish. In fish, lysozyme is found in phagocytic cells, serum, mucus, and ova. It is a hydrolytic enzyme able to cleave the cell wall of Gram-positive and some Gramnegative bacteria. By measuring this parameter, it is possible to analyze the immunosuppression exerted by the exposure of catfish to AFB1. We were able to identify a decrease of lysozyme activity in both treatments; however, in the group supplemented with Mycofix, the decrease of lysozyme activity was less pronounced. For instance, the diet containing $200 \mu \mathrm{g} / \mathrm{kg}$ of AFB1 had lysozyme activity values equivalent to the diet containing $1,000 \mu \mathrm{g} / \mathrm{kg}$ of AFB1 with Mycofix, showing that Mycofix had a protective effect against AFB1.

As in mammals, in fish some enzymes can be used as specific "liver-guiding enzymes" that can be a sensitive indicator of hepatotoxic effects, GPT and GOT being two of those (Krajnovic-Ozretic and Ozretic 1987). These enzymes are found in small concentrations in plasma, derived probably from the regular physiological shedding of cells (Schmidt and Schmidt 1974). Therefore, any detectable increase of their activity in plasma can be a reliable indicator of not only changed metabolic functions but also of structural damage at tissue level, so the interpretation of results from these enzymes should be done carefully (Krajnovic-Ozretic and Ozretic 1987). In the present trial we observed an increasing value of GPT and GOT in response to the increasing values of AFB1 in the diets, suggesting tissue damage. These parameters confirm that Mycofix effectively protected the fish against structural damage at tissue level, caused by AFB1. Regarding BUN and uric acid, no strong conclusions menor aumento de peso y menor eficiencia alimenticia, a un nivel inferior de AFB1 $(3 \mu \mathrm{g} / \mathrm{kg})$. Estas discrepancias se pueden atribuir a diferencias de sexo, edad y localidad, o a diferentes condiciones ambientales o nutricionales (Eaton y Groopman 1994), así como al tiempo de exposición que cambia la forma en que el animal maneja la toxina.

En el presente estudio, los tratamientos que contenían Mycofix Secure mostraron una disminución de los efectos negativos sobre el crecimiento y la supervivencia (aumento de peso, TCE y TCA) en comparación con los tratamientos sin el aglutinante. Las dietas con el aglutinante mostraron una menor reducción en aumento de peso en comparación con las dietas sin éste. Es interesante notar una acentuada disminución en ganancia de peso entre 500 y $1,000 \mu \mathrm{g} / \mathrm{kg}$ de AFB1, lo que sugiere que éste es el nivel en que la especie empieza a tener dificultades para lidiar con el daño biológico de las toxinas. La presencia de AFB1 en la dieta afecta negativamente la TCA de $P$. fulvidraco. En el tratamiento A-10M el aglutinante mejoró la TCA en un $24 \%$ en comparación con el tratamiento respectivo sin Mycofix (A-10). En general, Mycofix mejoró la TCA en comparación con el grupo control. Aunque las diferencias no son estadísticamente significativas, desde una perspectiva económica, la mejoría en la TCA (e.g., 24\% para el nivel de 1,000 $\mu \mathrm{g} / \mathrm{kg}$ de AFB1) representa un ingreso real para los acuicultores.

La AFB1 también es un potente modulador inmunológico, lo que provoca la supresión del sistema inmune (Ottinger y Kaattari 1998) y consecuentemente afecta los valores normales de la proteína total, albúmina, globulina y relación A:G. Se han asociado niveles anormales de estas proteínas con la hemólisis o mayor desintegración de las células rojas de la sangre y/o daño hepático (Islam et al. 2004). El hígado ayuda a descomponer la bilirrubina en la sangre, por lo que el daño hepático puede provocar el color amarillo pálido que presentan los peces enfermos y que es descrito como un posible síntoma de la micotoxicosis en peces. En el presente trabajo, la reducción de la proteína total y una mayor relación A:G confirmó la inmunosupresión de $P$. fulvidraco. Tanto la globulina como la albúmina son producidas por el hígado y si éste es dañado, ya no puede producir estas proteínas. Por lo tanto, es posible concluir que la reducción del nivel de proteína total puede estar relacionada con trastornos hepáticos y renales debido a la ingestión de AFB1. La mayor relación A:G sugiere una subproducción de inmunoglobulinas, lo cual indica una supresión del sistema inmune. Asimismo, la naturaleza inmunosupresora de AFB1 en el bagre amarillo puede confirmarse por la menor actividad bactericida, que se puede asociar con la pobre capacidad de destrucción de bacterias por los factores antimicrobianos del suero de peces tratados con la concentración más alta de AFB1. En el caso de las dietas que carecían Mycofix, el número de colonias bacterianas en la dieta A-10 fue significativamente mayor que en el tratamiento control, lo que muestra un efecto claro de la AFB1 en los factores antimicrobianos del suero. En general, los valores de la actividad de la 
could be obtained from these parameters; however, values increased when animals were fed diets containing increasing quantities of mycotoxins. This suggests a change in metabolism function or/and structural damage at tissue level, that probably could not be detected by macroscopic examination in such a short-term trial.

In conclusion, the yellow catfish is sensitive to the presence of AFB1 in the diet. A negative relationship between the AFB1 level in the diet and fish survival, growth performance, feed efficiency, and immunological parameters was observed. Diets containing $1,000 \mu \mathrm{g} / \mathrm{kg}$ of AFB1 were highly toxic to yellow catfish. The use of the AFB1 binder (Mycofix) decreased the negative impact of AFB1 toxicity on the fish. While not statistically different in some cases, the results obtained represent an important step for counteracting AFB1 in aquaculture.

\section{REFERENCES}

Abd-Allah GA, El-Fayoumi RI, Smith MJ, Heckmann RA, O’Neill KL. 1999. A comparative evaluation of aflatoxin B1 genotoxicity in fish models using the Comet assay. Mutat. Res./ Genet. Toxicol. Environ. Mutag. 446: 181-188.

Anh Tuan N, Grizzle JM, Lovell RT, Manning BB, Rottinghaus GE. 2002. Growth and hepatic lesions of Nile tilapia (Oreochromis niloticus) fed diets containing aflatoxin B1. Aquaculture 212: 311-319.

Bailey GS, Loveland PM, Pereira A, Pierce D, Hendricks JD, Groopman JD. 1994. Quantitative carcinogenesis and dosimetry in rainbow trout for aflatoxin B1 and aflatoxicol, two aflatoxins that form the same DNA adduct. Mut. Res./Environ. Mutag. Related Subj. 313: 25-38.

Binder EM, Tan LM, Chin LJ, Handl J, Richard J. 2007. Worldwide occurrence of mycotoxins in commodities, feeds and feed ingredients. Anim. Feed Sci. Technol. 137: 265-282.

BIOMIN 2014. Mycotoxin Survey 2012 (BIOMIN Holding). Austria.

Bradford MM. 1976. A rapid and sensitive method for the quantitation of microgram quantities of protein utilizing the principle of protein-dye binding. Anal. Biochem. 72: 248-254.

Bryden WL. 2011. Mycotoxins: Natural food chain contaminants and human health. In: Nriagu JO (ed.), Encyclopedia of Environmental Health. Elsevier, Burlington, pp. 898-905.

Burgos-Hernández A, Farias SI, Torres-Arreola W, Ezquerra-Brauer JM. 2005. In vitro studies of the effects of aflatoxin B1 and fumonisin B1 on trypsin-like and collagenase-like activity from the hepatopancreas of white shrimp (Litopenaeus vannamei). Aquaculture 250: 399-410.

Busby WF, Wogan GN. 1984. Aflatoxins. In: Searle CE (ed.), Chemical Carcinogenesis. American Chemical Society, Washington, DC, pp. 945-1136.

Carlson DB, Williams DE, Spitsbergen JM, Ross PF, Bacon CW, Meredith FI, Riley RT. 2001. Fumonisin B1 promotes aflatoxin $\mathrm{B} 1$ and N-methyl-N'-nitro-nitrosoguanidine-initiated liver tumors in rainbow trout. Toxicol. Appl. Pharmacol. 172: 29-36.

Council for Agricultural Science and Technology. 2003. Mycotoxins: Risks in plant, animal and human systems. In: CAST (ed.), Task Force Report, Technology, Ames, IA.

Chávez-Sánchez MC, Martínez Palacios CA, Osorio MI. 1994. Pathological effects of feeding young Oreochromis niloticus diets supplemented with different levels of aflatoxin B1. Aquaculture 127: 49-60. vía alternativa del complemento de peces son considerablemente mayores que los de mamíferos, lo que sugiere que esta vía de activación del sistema del complemento es particularmente relevante para los peces como un mecanismo del sistema inmune no específico (Yano et al. 1988, Sunyer y Tort 1995). En nuestro estudio, no fue posible evaluar la relación entre la AFB1 ingerida y los valores de la vía alternativa del complemento.

De forma similar, la lisozima de peces parece ser más activa que la de vertebrados mayores y es capaz de eliminar una variedad de patógenos bacterianos (Yousif et al. 1994). El sistema inmune innato de peces se considera la defensa principal contra un amplio espectro de agentes patógenos y es más importante para los peces que para los mamíferos, y la actividad de la lisozima es un índice importante de la inmunidad innata de peces. En peces, la lisozima se encuentra en las células fagocíticas, el suero, el moco y los huevos. Es una enzima hidrolítica que puede adherirse a la pared celular de bacterias grampositivas y algunas bacterias gramnegativas. La medición de este parámetro permite analizar la inmunosupresión causada por la exposición de $P$. fulvidraco a la AFB1. Fue posible identificar una disminución de la actividad de la lisozima en ambos ensayos; sin embargo, en el grupo que recibió Mycofix, la disminución de la actividad fue menos pronunciada. Por ejemplo, los valores de la actividad de la lisozima para la dieta que contenía $200 \mu \mathrm{g} / \mathrm{kg}$ de AFB1 fueron iguales a los de la dieta que se elaboró con $1,000 \mu \mathrm{g} / \mathrm{kg}$ de AFB1 con Mycofix, lo que muestra que el aglutinante tuvo un efecto protector contra la AFB1.

Al igual que en los mamíferos, en los peces algunas enzimas pueden ser usadas como indicadores sensibles de efectos hepatotóxicos, tales como GPT y GOT (KrajnovicOzretic y Ozretic 1987). Estas enzimas se encuentran en concentraciones pequeñas en el plasma, probablemente derivadas de la descamación fisiológica regular de células (Schmidt y Schmidt 1974). Por lo tanto, cualquier incremento detectable de su actividad en el plasma puede ser un indicador confiable de tanto funciones metabólicas alteradas como de daño estructural a nivel de tejido, por lo que los resultados de estas enzimas deben interpretarse con cuidado (KrajnovicOzretic y Ozretic 1987). En el presente trabajo se observó un aumento de los valores de GPT y GOT en respuesta a los valores crecientes de AFB1 en las dietas, lo que sugiere daño tisular. Estos parámetros confirman que Mycofix efectivamente protegió los individuos contra daño estructural a nivel de tejido causado por la AFB1. En cuanto al ácido úrico y BUN, no se obtuvieron conclusiones sólidas de estos parámetros, pero los valores aumentaron cuando los animales se alimentaron con las dietas que contenían mayores cantidades de micotoxinas. Esto sugiere un cambio en la función del metabolismo y/o damaño estructural a nivel de tejido que probablemente no fue posible detectar mediante examinación macroscópica en este experimento a corto plazo.

En conclusión, el bagre amarillo es sensible a la presencia de AFB1 en la dieta. Se observó una relación negativa entre 
Chestnut AB, Anderson PD, Cochran MA, Fribourg HA, Gwinn KD. 1992. Effects of hydrated sodium calcium aluminosilicate on fescue toxicosis and mineral absorption. J. Anim. Sci. 70: 2838-2846.

Ciegler A, Burmaister HR, Vesonder RF, Hesseltine CW. 1981. Mycotoxins: Occurrence in the environment. In: Shank RCE (ed.), Mycotoxins and N-Nitro-Compounds: Environmental Risks. CRC Press, Boca Raton, FL, pp. 1-50.

Cole RJ, Cox RH. 1981. Handbook of Toxic Fungal Metabolites. Academic Press, New York.

Deng SX, Tian LX, Liu FJ, Jin SJ, Liang GY, Yang HJ, Du ZY, Liu YJ. 2010. Toxic effects and residue of aflatoxin B1 in tilapia (Oreochromis niloticus $\times$ O. aureus) during long-term dietary exposure. Aquaculture 307: 233-240.

Eaton DL, Groopman J. 1994. The Toxicology of Aflatoxins. Human Health, Veterinary and Agricultural Significance. Academic Press, New York.

El-Banna R, Teleb HM, Hadi MM, Fakhry FM. 1992. Performance and tissue residue of tilapia fed dietary aflatoxin. Vet. Med. J. Giza 40: 17-23.

El-Sayed YS, Khalil RH. 2009. Toxicity, biochemical effects and residue of aflatoxin B1 in marine water-reared sea bass (Dicentrarchus labrax L.). Food Chem. Toxicol. 47: 1606-1609.

El-Sayed YS, Khalil RH, Saad TT. 2009. Acute toxicity of ochratoxin-A in marine water-reared sea bass (Dicentrarchus labrax L.). Chemosphere 75: 878-882.

Ellis AE. 1990. Lysozyme assays. In: Stolen JS, Fletcher TC, Anderson DP, Robertson BS, van Muiswinkel WB (eds.), Techniques in Fish Immunology: FITC 1. SOS Publications, Fair Haven, NJ, pp. 101-103.

Gallagher EP, Eaton DL. 1995. In vitro biotransformation of aflatoxin B1 (AFB1) in channel catfish liver. Toxicol. Appl. Pharmacol. 132: 82-90.

Galvano F, Pietri A, Bertuzzi T, Fusconi G, Galvano M, Piva A, Piva G. 1996. Reduction of carry over of aflatoxin from cow feed to milk by addition of activated carbons. J. Food Prot. 59: 551-554.

Galvano F, Piva A, Ritieni A, Galvano G. 2001. Dietary strategies to counteract the effects of mycotoxins: A review. J. Food Prot. 64: $120-131$.

Hanson AM, Kittilson JD, Martin LE, Sheridan MA. 2014. Environmental estrogens inhibit growth of rainbow trout (Oncorhynchus mykiss) by modulating the growth hormoneinsulin-like growth factor system. Gen. Comp. Endocrinol. 196: 130-138.

Hassan AM, Kenawy AM, Abbas WT, Abdel-Wahhab MA. 2010. Prevention of cytogenetic, histochemical and biochemical alterations in Oreochromis niloticus by dietary supplement of sorbent materials. Ecotoxicol. Environ. Saf. 73: 1890-1895.

Hooft JM, Elmor A, Ibraheem EH, Encarnação P, Bureau DP. 2011. Rainbow trout (Oncorhynchus mykiss) is extremely sensitive to the feed-borne Fusarium mycotoxin deoxynivalenol (DON). Aquaculture 311: 224-232.

Huang Y, Han D, Zhu X, Yang Y, Jin J, Chen Y, Xie S. 2011. Response and recovery of gibel carp from subchronic oral administration of aflatoxin B1. Aquaculture 319: 89-97.

Hussein HS, Brasel JM. 2001. Toxicity, metabolism and impact of mycotoxins on humans and animals. Toxicol. Appl. Pharmacol. 167: 101-134.

[IARC] International Agency for Research on Cancer. 1993. WHO IARC Monographs on the Evaluation of Carcinogenic Risk to Humans. Some naturally occurring substances: Food items and constituents, heterocyclic aromatic amines and mycotoxins. Aflatoxins. Vol. 56, IARC, Lyon, France, pp. 245-395. el nivel de AFB1 en la dieta y la supervivencia, el crecimiento, la eficiencia alimenticia y los parámetros inmunológicos de los peces. Las dietas elaboradas con $1,000 \mu \mathrm{g} / \mathrm{kg}$ de AFB1 fueron muy tóxicas para los individuos. El uso del aglutinante de AFB1 (Mycofix) disminuyó el efecto negativo de la toxicidad de AFB1. A pesar de que los resultados no fueron estadísticamente diferentes en algunos casos, representan un paso importante para contrarrestar los efectos negativos de la AFB1 en la acuicultura.

Traducido al español por Christine Harris.

Islam MS, Lucky NS, Islam MR, Ahad A, Das BR, Raham MM, Siddiqui MSI. 2004 Haematological parameters of Fayoumi, Assil and local chickens reared in Sylhet region in Bangladesh. Int. J. Poult. Sci. 3: 144-147.

Jantrarotai W, Lovell RT. 1990. Subchronic toxicity of dietary aflatoxin B1 to channel catfish. J. Aquat. Anim. Health 2: 248-254.

Kajita K. 1990 Strongly correlated two dimensional electrons formed on dielectric materials. In: Ichimaru S (ed.), Strongly Coupled Plasma Physics. Elsevier, pp. 275-284.

Krajnovic-Ozretic M, Ozretic B. 1987. Estimation of the enzymes LDH, GOT and GPT in plasma of grey mullet Mugil auratus and their significance in liver intoxication. Dis. Aquat. Org. 3: 187-193.

Kubena LF, Harvey RB, Huff WE, Elissalde MH, Yersin AG, Phillips TD, Rottinghaus GE. 1993. Efficacy of a hydrated sodium calcium aluminosilicate to reduce the toxicity of aflatoxin and diacetoxyscirpenol. Poult. Sci. 72: 51-59.

Lumlertdacha S, Lovell RT, Shelby RA, Lenz SD, Kemppainen BW. 1995. Growth, hematology, and histopathology of channel catfish, Ictalurus punctatus, fed toxins from Fusarium moniliforme. Aquaculture 130: 201-218.

Luo Z, Tan X-Y, Zheng J-L, Chen Q-L, Liu C-X. 2011. Quantitative dietary zinc requirement of juvenile yellow catfish Pelteobagrus fulvidraco, and effects on hepatic intermediary metabolism and antioxidant responses. Aquaculture 319: 150-155.

Manning BB, Li MH, Robinson EH. 2005. Aflatoxins from mouldy corn cause no reductions in channel catfish Ictalurus punctatus performance. J. World Aquacult. Soc. 36: 59-67.

Massey TE, Stewart RK, Daniels JM, Liu L. 1995. Biochemical and molecular aspects of mammalian susceptibility to aflatoxin B1 carcinogenicity. Proc. Soc. Exp. Biol. Med. 208: 213-227.

McKean C, Tang L, Tang M, Billam M, Wang Z, Theodorakis CW, Kendall RJ, Wang JS. 2006. Comparative acute and combinative toxicity of aflatoxin B1 and fumonisin B1 in animals and human cells. Food Chem. Toxicol. 44: 868-876.

Miller JD, Trenholm HL (eds.). 1994. Mycotoxins in Grain: Compounds other than Aflatoxins, Eagan Press, St. Paul, MN.

Ngethe S, Horsberg TE, Mitema E, Ingebrigtsen K. 1993. Species differences in hepatic concentration of orally administered $3 \mathrm{H}$ AFB1 between rainbow trout (Oncorhynchus mykiss) and tilapia (Oreochromis niloticus). Aquaculture 114: 355-358.

Ostrowski-Meissner HT, LeaMaster BR, Duerr EO, Walsh WA. 1995. Sensitivity of the Pacific white shrimp, Penaeus vannamei, to aflatoxin B1. Aquaculture 131: 155-164.

Ottinger CA, Kaattari SL. 1998. Sensitivity of rainbow trout leucocytes to aflatoxin B1. Fish Shellfish Immunol. 8: 515-530. 
Ottinger CA, Kaattari SL. 2000. Long-term immune dysfunction in rainbow trout (Oncorhynchus mykiss) exposed as embryos to aflatoxin B1. Fish Shellfish Immunol. 10: 101-106.

Plumb JA, Horowitz SA, Rogers WA. 1986. Feed-related anemia in cultured channel catfish (Ictalurus punctatus). Aquaculture 51: $175-179$.

Richard J. 2000. Sampling and sample preparation for mycotoxin analysis. Romer Labs Guide to Mycotoxins. Vol. 2. Romer Lab Inc., Union, MO.

Sahoo B, Saraswat ML, Haque N, Khan MY. 1999. Energy balance and methane production in sheep fed chemically treated wheat straw. Small Ruminant Res. 35: 13-19.

Sahoo PK, Mukherjee SC. 2001. Effect of dietary $\beta-1,3$ glucan on immune responses and disease resistance of healthy and aflatoxin B1-induced immunocompromised rohu (Labeo rohita Hamilton). Fish Shellfish Immunol. 11: 683-695.

Schmidt E, Schmidt FW. 1974. The importance of enzymatic analysis In: Bergmeyer HU (ed.), Medicine Principles: Methods of Enzymatic Analysis. Academic Press, New York, pp. 6-14.

Sharma RP, Salunkhe DK. 1991. Mycotoxins and Phytotoxins. CRC Press, Boca Raton, FL.

Smith TK, McMillan EG, Castillo JB. 1997. Effect of feeding blends of Fusarium mycotoxin-contaminated grains containing deoxynivalenol and fusaric acid on growth and feed consumption of immature swine. J. Anim. Sci. 75: 2184-2191.

Sudakin DL. 2003. Trichothecenes in the environment: Relevance to human health. Toxicol. Lett. 143: 97-107.

Sunyer JO. Tort L. 1995. Natural hemolytic and bactericidal activities of sea bream Sparus aurata serum are effected by the alternative complement pathway. Vet. Immunol. Immunopathol 45: 333-345.

Tan X-Y, Luo Z, Xie P, Liu X-J. 2009. Effect of dietary linolenic acid/linoleic acid ratio on growth performance, hepatic fatty acid profiles and intermediary metabolism of juvenile yellow catfish Pelteobagrus fulvidraco. Aquaculture 296: 96-101.

Tuan NA, Grizzle JM, Lovell RT. Manning BB, Rottinghaus GE, 2002. Growth and hepatic lesions of Nile tilapia (Oreochromis niloticus) fed diets containing aflatoxin B1. Aquaculture 212: 311-319.

Wang J-S, Groopman JD. 1999. DNA damage by mycotoxins. Mutat. Res./Genet. Toxicol. Environ. Mutag. 424: 167-181.

Wang, J-S, Kensler TW, Groopman JD. 1998. Toxicants in food: Fungal contaminants. In: Ioannides CE (ed.), Nutrition and Chemical Toxicity. Wiley, pp. 29-57.

Yano T. 1996. The nonspecific immune system: Humoral defense. In: Iwama G, Nakanishi T (eds.), The Fish Immune System: Organism, Pathogen and Environment. Academic Press, San Diego, CA, pp. 105-157.

Yano T, Hatayama Y, Matsuyama H, Nakao M. 1988. Titration of the alternative complement pathway activity of representative cultured fishes. Nippon Suisan Gakkaishi 54: 1049-1054.

Yousif AN, Albright LJ, Evelyn TPT. 1994. Purification and characterization of a galactose-speciflc lectin from the eggs of coho salmon Oncorhynchus kisutch, and its interaction with bacterial fish pathogens. Dis. Aquat. Org. 20: 127-136.

Zaki MS, Sharaf NE, Rashad H, Mastala SO, Fawz QM. 2008. Diminution of aflatoxicosis in tilapia nilotica fish by dietary supplementation with fix in toxin and Nigella sativa oil. Am.-Euras. J. Agric. Environ. Sci. 3: 211-215.

Zychowski KE, Pohlenz C, Mays T, Romoser A, Hume M, Buentello A, Gatlin III DM, Phillips TD. 2013. The effect of NovaSil dietary supplementation on the growth and health performance of Nile tilapia (Oreochromis niloticus) fed aflatoxin-B1 contaminated feed. Aquaculture 376-379: $117-123$.

Received October 2015, accepted January 2016. 